\title{
Research in Sustainability of Chain Conveyor Systems
}

\author{
Lynn Lüdemann*, Jens Sumpf, Markus Golder, Marcus Bona \\ Professorship of Conveying Engineering and Materials Handling, Chemnitz University of Technology, Germany \\ * Correspondence:lynn.luedemann@mb.tu-chemnitz.de
}

Received 22 October 2020; Accepted 26 October 2020; Available online 7 December 2020

(C) 2020 by L. Lüdemann et al. This is an open access article distributed under the Creative Commons Attribution License (CC-BY 4.0), which permits unrestricted use, distribution, and reproduction in any medium, provided the original work is properly cited.

\begin{abstract}
Climate Change is a crucial challenge of today. The main reason is increased man-made emissions of climate gases, like $\mathrm{CO}$, into the atmosphere. In every part of our life, these emissions have to be reduced. Transport of goods, called intra- or extralogistics, is necessary for economic welfare. Intralogistics means the transport of goods in distribution centres or manufacturing spaces, e. g. between machines. For continuous transport processes chain conveyor systems (CCS) are state of the art. The research group "Plastic Components and Tribology" at professorship of Conveying Engineering and Materials Handling focus on impacts of their whole life cycle, from design over use until end-of-life, on the environment. Another focus is the development of Environmental Product Declaration (EPD) for chain conveyor systems. They are useful to promote environmentally-friendly products and to push eco-design activities. But also, activities of circular economy such as recycling of the plastic parts from conveyor chains are examined. The article gives an overview of the goals achieved and the challenges ahead. Some of the achieved results will be presented.
\end{abstract}

KEYWORDS life cycle assessment, circular economy, environmental product declaration, EPD, product category rule, PCR, recyclability

\section{Introduction}

Climate change is caused by man-made emissions of climate gases like carbon dioxide, nitrous oxide, methane. They have an effect on the temperature in the atmosphere of our planet. Climate gases have a radiative force, which repels sun in our atmosphere. Following the findings of the International Panel of Climate Change (IPCC) the temperaturedevelopment shows a warming of $0.85^{\circ} \mathrm{C}$ between 1880 and 2012. This is measurable at every place of the earth [1]. Warming in the atmosphere causes rising ocean levels, smelting ice shields and an increase of heavy weather events.

Energy consumption for production, traffic and heating by using non-renewable fuels as oil, coal or wood is the main causer of carbon dioxide emissions. An increased consumption of meat, causes a lot of methane emissions and cultivation of animal fodder enhances this effect. Figures 1 and 2 show the necessity and the opportunities of 

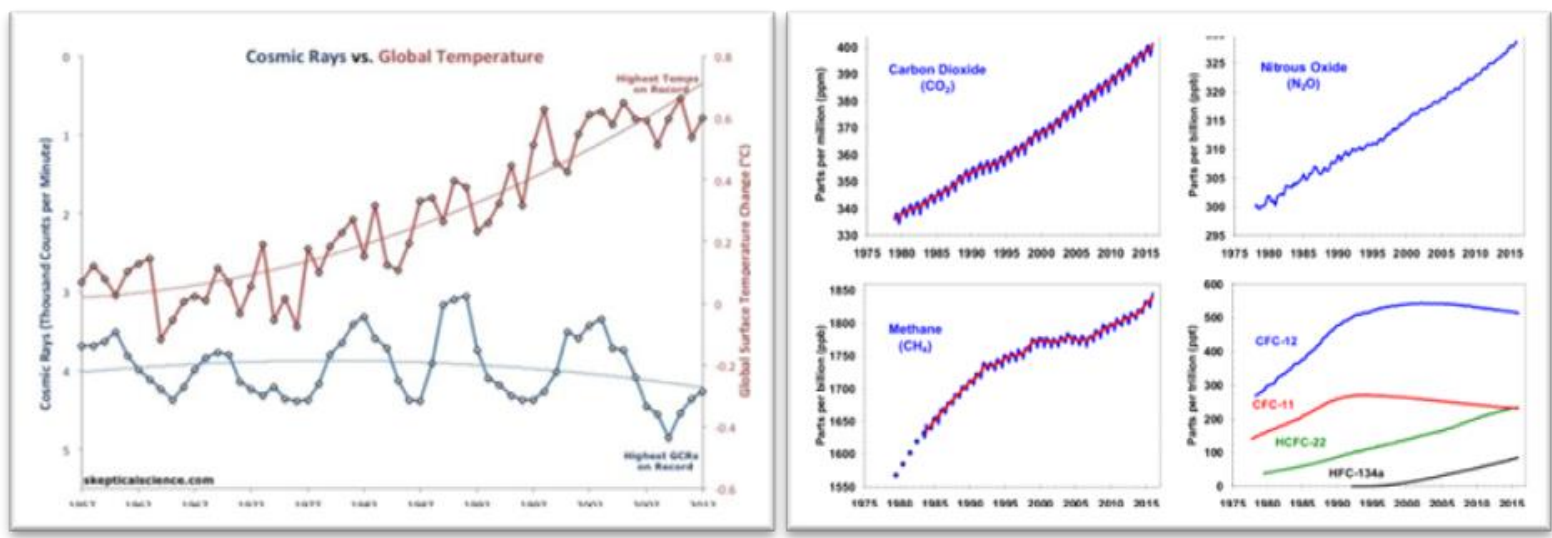

Figure 1: Increase of Global Temperature and of Climate Gas Emission [3]

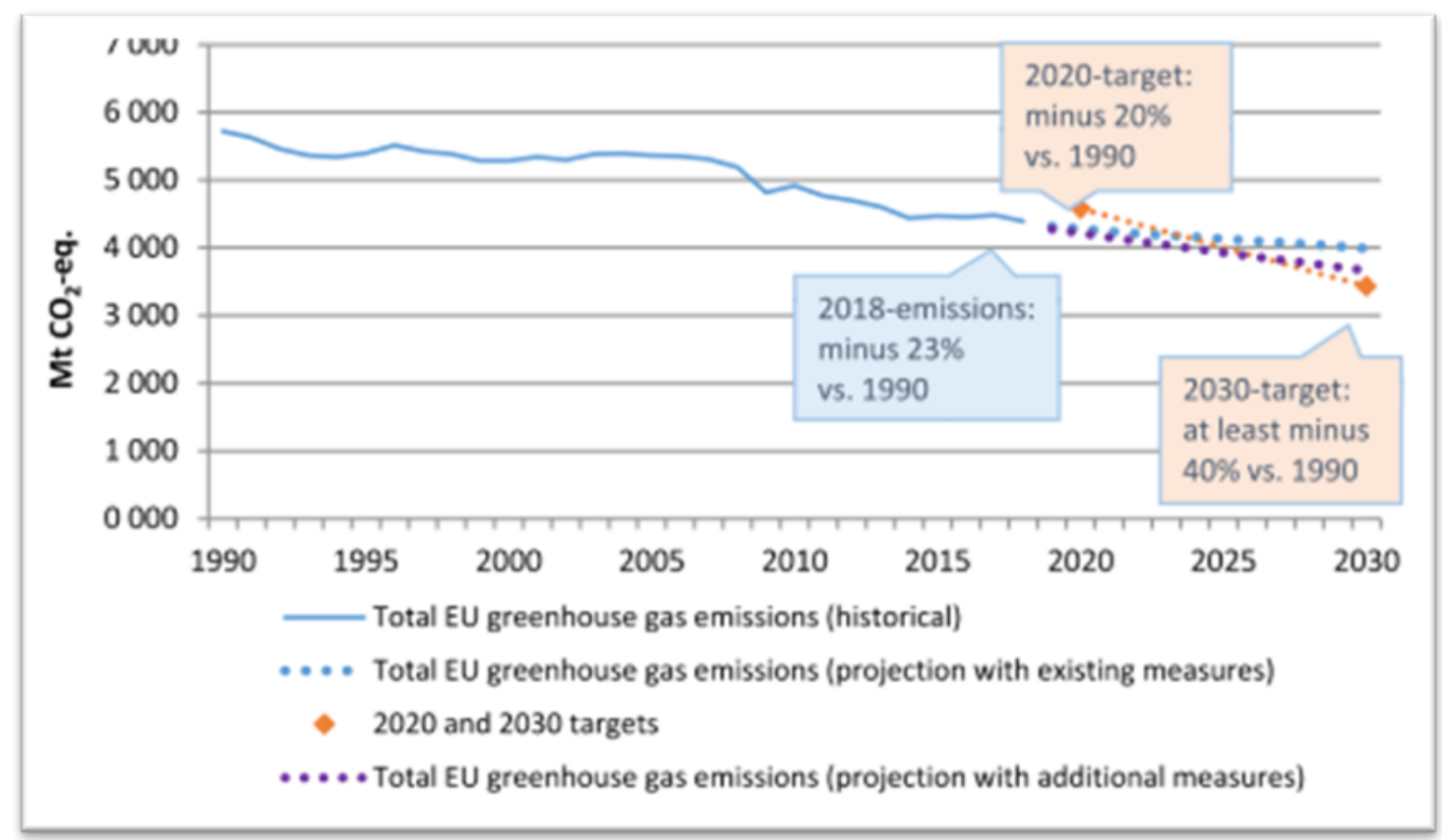

Figure 2: Total EU GHG emissions including international aviation and GHG reduction targets [4]

cutting the emissions of climate gases. The first figure shows on the left side the increase of the global temperature vs. the cosmic rays, which are often counted as cause for the temperature. No interaction can be demonstrated. On the right side, the measured climate gas concentration is illustrated, a clear grow is recognizable.

Figure 2 is from the report "Preparing the ground for raising long-term ambition EU Climate Action Progress Report 2019” [3] As documented in this report the targets are high but feasible. The main emissions come from electricity and heat production and industry, they fell by $4.1 \%$ from 2017 to 2018. One key for this success is renewed EU emissions trading system (EU ETS).

The Climate and Energy Framework of the EU counts also on augmenting the energy efficiency (up to $20 \%$ until 2020 and more than $32.5 \%$ until 2030). Take the example of the transport sector: after a decrease in emissions (2007-2013), the emissions have increased in the last five years - this lead to a total reduction of less than $3 \%$ compared to 2005 . Transport 
emissions have to be reduced by $18 \%$ until 2030 . This should be reached with policy measures like CO2 Emission standards for new cars. Other measurements include land use changes and reforestation activities.

Efficiency means increasing the output, e.g. power, by constant input, e.g. electricity or vice versa constant output with decreasing input ${ }^{1}$. On the basis of the rules of the eco-design directive [5], more efficient devices, such as refrigerators or washing-machines have been developed. If rebound-effects ${ }^{2}$ can be avoided, a real reduction of energy-consumption is feasible. In the European Union a reduction about $20 \%$ has been reached within the last 20 years. This was also due to the introduction of environmental labels, which honour environmental friendliness.

From a larger point of view, sustainability is based on three pillars: ecology, economy and sociality. There are three main strategies to reach sustainability, the explained efficiency, accompanied by sufficiency and consistency.

Sufficiency targets the excessive consumption of goods as such. Sufficiency is a very important factor for reaching sustainability. According to Allwood e.g. car-sharing and ridesharing can reduce the environmental impact of car-production by 99.2 [2].

Consistency means the development of environmentally friendly technologies, which use the performance of the nature, without destroying it. Also, circular economy is part of the consistency, e.g. the use of trash as resource. All three strategies have to be thought together.

\section{Research Focus}

As mentioned above chain conveyor systems (CCS) are indispensable within a manufacturing-place, thus consume a significant part of energy and are usually replaced within each change of product programme. For several years our research focus process from the optimization of tribological and mechanical properties to the effects of this optimization on environmental aspects.

For assessing the environmental performance of products or processes life cycle assessments (LCA) are state-of the art. Therefore, the paper starts with a short introduction into the topic of LCA, followed by implementation within CCS, subsequently the achieved results are demonstrated. Afterwards, their applications, like environmental product declarations will be introduced.

\footnotetext{
${ }^{1}$ Energy efficiency is using technology that requires less energy to perform the same function.

${ }^{2}$ A typical rebound effect is the purchase of a more efficient, but bigger refrigerator, so that efficiency savings are abandoned.
} 


\section{Research Topics}

\subsection{Theory of Life Cycle Assessment}

Life Cycle Assessment (LCA) is a scientific method to evaluate the environmental impacts of products or services. It has two main features:

- Its relative nature, expressed by the functional Unit (FU)

- Cradle-to-grave (or cradle-to-cradle) calculation

The main idea of cradle-to-grave analysis is the implementation of the whole life cycle, thus avoiding environmental burden shifting. In Figure 3 the cradle-to-gate life cycle is designed. If parts of the waste can be used as new input (represented by the dotted arrow), real circular economy is achieved. Other expressions for the phases are Up-Stream (resource extraction), Core (production, manufacturing) and Downstream (use and recycling).

LCA compromise four steps, which are ruled by two international standards, the ISO 14040 and ISO 14044 [6][7]. All four mentioned phases interact with the other, represented by the double arrow, and their results can influence the other. The goal and scope phase comprise the definition of functional unit, reference flow, the choice of life cycle impact methods and the purpose of the study. The functional unit is a crucial concept of LCA. It means that all examinations are referred to the function of the product system. For illustrating this concept an example is used. Within the comparison of different beverage containers, not the product "bottles" should be compared (glass bottle vs. PET), it has to be the "beverage providing", e.g. 1.000 Litres. Therefore, you need 50 glass-bottles plus washing service or 1.000 PETbottles. This is called reference flow, which is the name for the physical amount of products to fulfil the chosen functional unit.

In the second phase the life cycle inventory is calculated. The life cycle is divided into processes and for each process the input and output flows are collected. To this end a pc program is used such as open source (openLCA) and purchasing versions (SimaPro, GaBi). Furthermore, data are needed for building the product system - these data can be collected at the production place (specific data) or extracted from databases (generic data).

After building up the product system, the calculation of environmental impacts, follows. It must be differentiated between midpoint and endpoint impact categories. Midpoint categories are for example, global warming, terrestrial acidification and eutrophication they are directly applicable to the LCI results, via scientific relationships. Endpoint categories are influencing human's wellbeing like health, quality of ecosystems, climate change or resource depletion. They are calculated after normalization, weighting and assigning the midpoint categories.

The fourth phase comprise the interpretation of the results. This often includes a ranking, an identification of significant issues and sensitivity or consistency checks. Conclusions, limitations and recommendations can be drawn and leading to decisions concerning course of action or policy measures. Figure 3 shows some of the mentioned aspects of the LCA theory. 


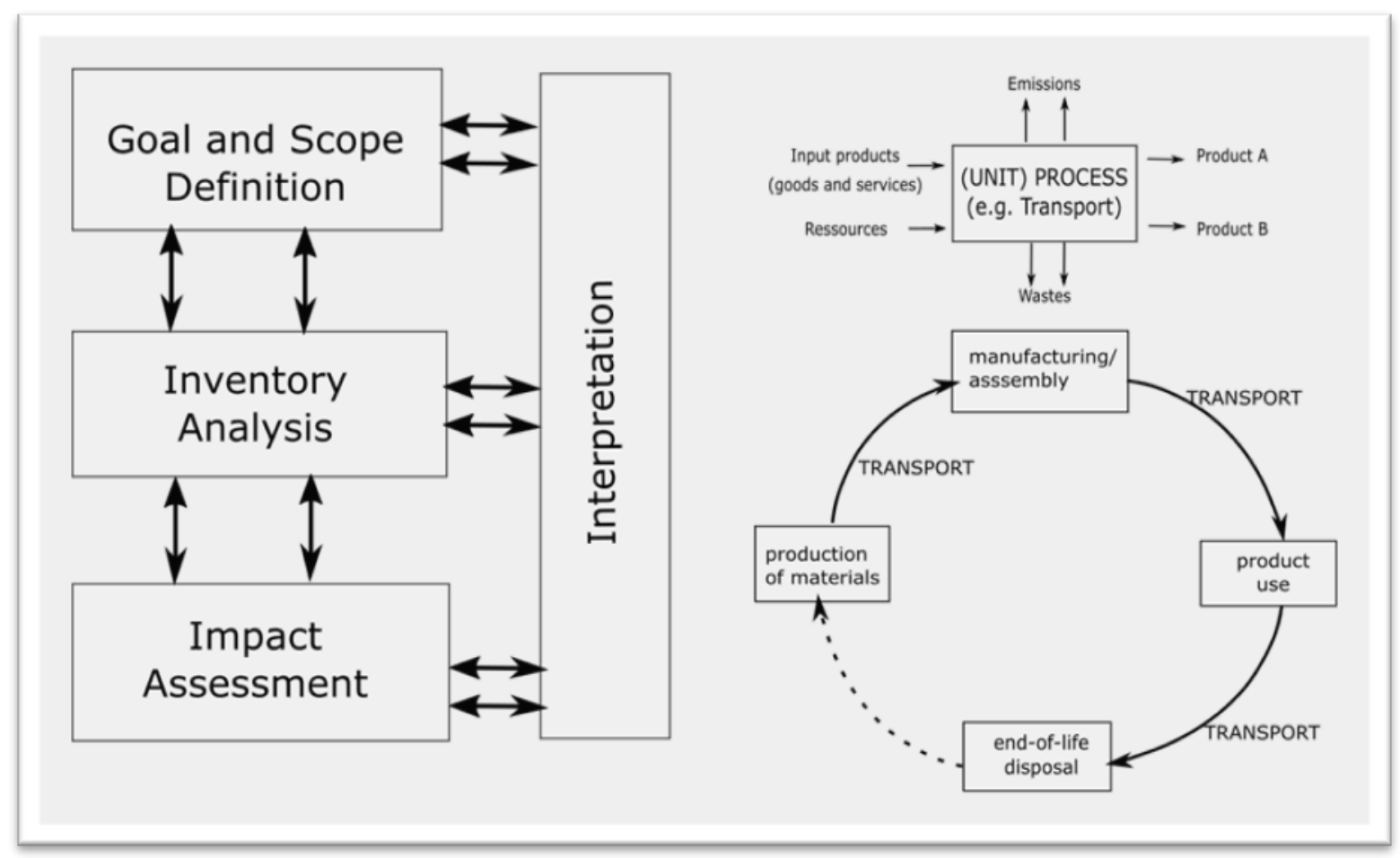

Figure 3: Aspects of LCA

\subsection{LCA of Chain Conveyor Systems}

In our project "Development of a Product Category Rule for continuous chain conveyer systems" we are researching about the influences of constructive changes on the LCA of CCS. One goal is the conjunction between reducing of friction (e.g. among slide rail and chain) and reducing of environmental impact.

As showed in 3.1 the first phase is goal and scope definition. The goal of the study is to find out about the influences on LCA results and to develop a product category rules (PCR) for CCS. This will be done within the calculation of "real-existing" CCS (e.g. for beverage-transport) and a representative model CCS, called "Referenzförderer" ${ }^{3}$. Furthermore, the definition of $\mathrm{FU}$ is an important part of this phase. The functional Unit is the quantified performance of a product system, to use as reference unit. (see 3.2 in [7]) Its definition comprises function and performance of the product, its size and unit have to be declared. Following the Guide of LCA from the Joint Research Centre of the European Union [9] the questions: what, how many, how good and how long, should be responded to find out the FU. In our CCS we chose

"Transportation of goods (expressed in $\mathrm{kg}$ ) on chain conveyor system (physical length, expressed in m) over a scheduled life-time - Unit $(\mathrm{kg} \times \mathrm{m} \times \mathrm{h})$ "

Our reference-conveyor is about $6.86 \mathrm{~m}$ long and weighs 154 kilograms. The chain is made from polyoxymethylene (POM), other plastic parts are from polyamide (PA) and

\footnotetext{
${ }^{3}$ Our model is a small CCS, with one curve and conveying route round about 6.86 meters.
} 
ultra-high molecular weight polyethylene (PE-UHMW), the frame is made of steel. We divided the life-cycle into the following 4 phases:

- Up-Stream I (extraction and production of raw materials, like plastic granulates, paper for packaging, steel, aluminium

- Up-Stream II: production of semi-finished products like injection-moulded parts, procurement of add-on components, e.g. engines

- Core: Transport of all parts to the manufacturer, storing and picking, assembly, prelaunch and testing

- Downstream: transport to the user, launch, use, maintenance, decommissioning, exploitation

The division of the Up-Stream phase into two phases is the result of intensive discussions with our business partners. The second Up-Stream phase is strongly influenced by its specifications, but does not take place inhouse. Therefore, it doesn't belong to the corephase.

Following the assumption of the Joint Research Center [9], we calculated the following environmental impact categories:

- Global warming potential (GWP)

- Acidification potential (AP)

- Eutrophication potential (EP)

- Ozone depletion potential (ODP)

- Abiotic resource depletion (ADP-fossil fuels)

The described approach is shown in Figure 4. The results support the presumed high influence of the use phase. For each environmental impact category, the influence of the use phase is top.

The different impact categories are calculated in so called "reference units", e.g. the global warming in $\mathrm{kg} \mathrm{CO}_{2}$-equivalents. This means for each gas with climate potential (induced by its radiative force), the $\mathrm{CO}_{2}$-equivalents are calculated. They depend on their climate force related to the climate force of $\mathrm{CO}_{2}$ (which is always set to 1) and their persistence in the atmosphere over the time. The formula is as follows:

$$
\mathrm{GWP}_{\mathrm{i}}=\frac{\int_{0}^{\mathrm{T}} \mathrm{a}_{\mathrm{i}} \times \mathrm{C}_{\mathrm{i}}(\mathrm{t}) \mathrm{dt}}{\int_{0}^{\mathrm{T}} \mathrm{a}_{\mathrm{CO} 2} \times \mathrm{C}_{\mathrm{CO}_{2}}(\mathrm{t}) \mathrm{dt}}
$$

whereas, $a_{i}$ is instantaneous radiative forcing due to a unit increase in the concentration of trace gas, $\mathrm{C} i$ is the concentration of the trace gas, remaining at time $t$ after its release and $n$ is the number of years over which the calculation is performed corresponding values for carbon dioxide are in the denominator (see Figure 8.28 in [10]).

As shown in Figure 4 a GWP of 14.8 tonnes $\mathrm{CO} 2$-eq for the use-phase, means the emission of different climate gases (e.g. $\left.\mathrm{CH}_{4}, \mathrm{CFC}-11, \mathrm{CFC}-115\right)$ within the use-time of our reference conveyor, summed up to carbon dioxide equivalents. The use phase accounts for about $95 \%$ of the GWP emissions, reductions concerning energy consumption can decrease this amount. 


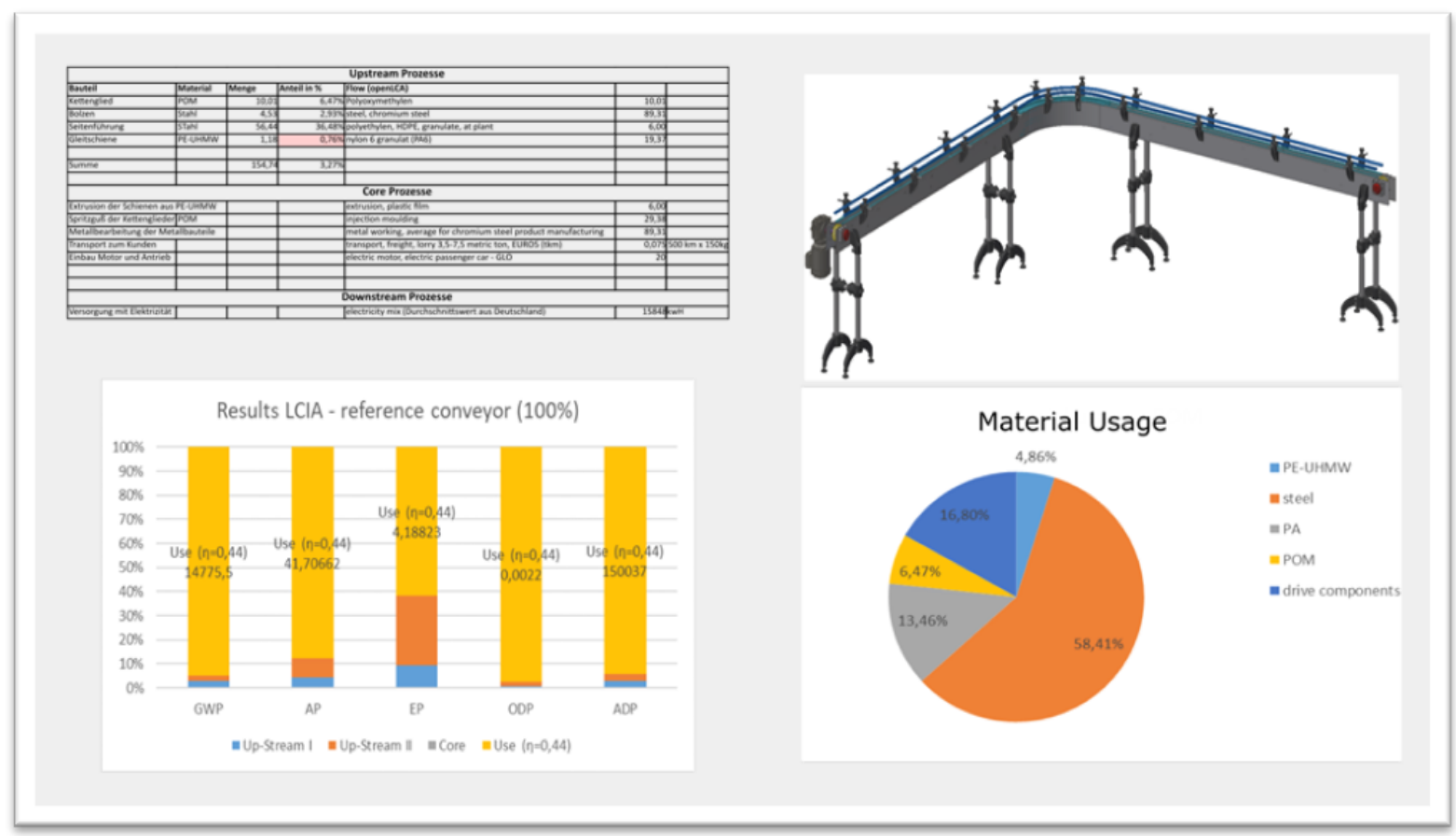

Figure 4: Reference conveyor, material composition, results of life cycle impact assessment, list of flows

The whole method delivers fictional results, because emissions of the past (resource extraction) are added to potential emissions of the future. If for example the electricity mix production in Germany changes, the emissions of climate gases will change too.

\subsection{Environmental Product Declaration}

As mentioned above one possibility for achieving the climate goals is to increase the efficiency of energy using products. Integrated product policy (IPP) is an initiative at the European Union aimed at reducing the environmental burden of products by using different policy instruments. You find instruments to pull at the demand side (consumption) and others to push the supply side (product development). Encouraging customers to choose more environmentally friendlier products belongs to the demand side, instruments are green procurement programs or eco-labelling schemes [11]. Today a lot of environmental labels and declaration schemes for products and services exist. At the ecolabelindex.com website 475 ecolabels in 199 countries and 25 industry sectors are listed [12]. Most of them belong to the Type II label of the three label types distinguished by the ISO (International Organization of Standardization). They can be found in the ISO $14020 \mathrm{ff}$ series. Table 1 gives an overview about characteristics and target groups of the different label types.

LCA can be performed in different ways, e.g. with different functional units or boundary settings, thus leading to totally different results, therefore the results cannot be used for product comparison. 
Table 1: Properties of the three different label types

\begin{tabular}{|c|c|c|c|}
\hline & ISO 14024 (Type I) & ISO 14021 (Type II) & ISO 14025 (Type III) \\
\hline Characteristics & $\begin{array}{l}\text { - Official label set up by } \\
\text { government or } \\
\text { institutions } \\
\text { - Point out products with } \\
\text { overall environmental } \\
\text { preferability } \\
\text { - Products within a specific } \\
\text { category }\end{array}$ & $\begin{array}{l}\text { - Most used label (more } \\
\text { than 420) } \\
\text { - Self-declaration of } \\
\text { environmental claims, } \\
\text { e.g. only grass-fed cow- } \\
\text { milk }\end{array}$ & $\begin{array}{l}\text { - EPD (environmental } \\
\text { product declaration) } \\
\text { - Providing } \\
\text { environmental data } \\
\text { based on predetermined } \\
\text { parameters (PCR) } \\
\text { - Often used in the } \\
\text { building sector }\end{array}$ \\
\hline LCA based? & Yes & Not necessary & Yes \\
\hline Target group & Business-to-Costumer & Business-to-Costumer & Business-to-Business \\
\hline $\begin{array}{l}\text { Risk / } \\
\text { Opportunities }\end{array}$ & $\begin{array}{l}\text { - Long development } \\
\text { process } \\
\text { - All environmental impacts } \\
\text { were taken into account } \\
\text { - Very reliable }\end{array}$ & $\begin{array}{l}\text { - Not independently } \\
\text { verified } \\
\text { - Risk of greenwashing }\end{array}$ & $\begin{array}{l}\text { - Product information } \\
\text { conveyed through a list } \\
\text { of parameters (PCR) } \\
\text { - No rating of the Data } \\
\text { (e.g. efficiency class) } \\
\text { - Difficulty to understand } \\
\text { for layman }\end{array}$ \\
\hline Examples & $\begin{array}{l}\text { Blue Angel (Germany), EU- } \\
\text { Ecolabel, }\end{array}$ & $\begin{array}{l}\text { ProPlanet, } \\
\text { Farming Method }\end{array}$ & $\begin{array}{l}\text { EPDs of international epd- } \\
\text { system (IES/ } \\
\text { environdec } \AA \text { ), } \\
\text { IBU (institute for building } \\
\text { and construction) }\end{array}$ \\
\hline
\end{tabular}

To communicate the positive results of an environmentally optimized product environmental product declarations (EPD), Type III (ISO 14025) are useful. They communicate the results of LCA. To augment its comparability, product category rules (PCR) for products which fulfil the same function, have to be developed. Furthermore, a program operator, who provides and manages the declaration scheme is indispensable.

In Germany the Institute Bauen und Umwelt e.V. (IBU) is a program operator for EPDs in the construction sector. In this sector the instrument EPD became very successful, because the environmental performance of a whole building can be calculated by connecting different EPDs together (e.g. windows, doors, insulation and more).

An investigation result into about 38 programs, 1215 PCR documents and more than 11.000 EPDs all over the world [13], [14] [15]. One of the most known program operators is the international epd-system (IES/ environdec ${ }^{\circledR}$ ), originally founded in Sweden, is it now a network with partners in Ireland, Norge, Slovakia, Brasilia, Austria, Australia and Turkey. They are responsible for about 50\% of the PCR documents and more than 1,500 EPDs have been published by the IES.

An EPD serve to publish LCA data of products as an information and marketing instrument. Beneath the construction sector, EPDs have been published for vehicles and transport equipment (e.g. train, aircrafts), for food \& beverages (e.g. noodles, milk) or machinery \& equipment like lifts. EPDs are product data sheets, which contain environmental information like GWP, ADP but also recycled content, use of renewable energy and more.

An EPD for CCS can only be published on the base of so-called Product Category Rules (PCR), as no PCR for CCS exists, the goal of the project was to develop one. Firstly, it should only be 
guilty for CCS, later it could be augmented for other conveyor technologies. Also, the development of a technical specification (ISO-TR), as it exists for some building components, should be explored.

\subsection{Development of Product Category Rule}

The IES uses the United Nations Central Product Classification (CNC) for structuring PCRs. Following this classification, conveyor chain systems belong to the class of Lifting and handling equipment and parts thereof (435), they can be found under 4355 Pneumatic and other continuous action elevators and conveyors for goods or materials. Furthermore, the IES have developed so called "General program instructions", a PCR development checklist and PCR Basic modules for support the development of new PCR documents. One of the first steps to perform is the research, if any equivalent PCR document for the chosen category exist - up to now, no fitting category could be found. Nonetheless other similar PCR documents, e.g. for lifts or rolling stock, have been analysed to learn about used functional unit and more.

As described above, EPDs should enable purchaser to compare and select products fulfilling the same function. That's why a part of our research concentrate on this purpose. For existing PCRs and an amount of still published EPDs, a comparison of results and fulfilment has been examined [17]. Obviously, no good compliance concerning these requirements could be detected. The developing process for EPD/ PCR is long and costly (about \$13-41.000 and 22-44 working-days [16]). Even there is a huge increase for example in the construction sector, without any real stimulus the development will retard.

\subsection{Research Concerning End-of-Life}

Within the production of conveyor chain systems, a lot of material is needed. Normally this is sourced directly from nature, e.g. crude-oil to product plastic parts. Since the 2010s reducing material extraction for achieving resource neutrality is on the agenda of the European Union. The Circular Economy Package aims to establish a sustainable product policy framework, in order to make products fit for climate-neutral, resource-efficient and circular economy, thus to reduce waste and to ensure the performance of front-runners [17]. Among others the following measures are planned and relevant in our research focus:

- Improving product durability, reusability, upgradability and reparability

- Increasing recycled content in products, while ensuring their performance and safety

- Enabling remanufacturing and high-quality recycling

- Incentivising product-as-a-service

This can be adopted for chain conveyor systems. For the moment the focus is on detecting properties of recycled POM. First tests concerning mechanical and tribological properties show good results of reusability of this material. Another focus is the implementation of recycling in LCA calculations. At the Swedish Life Cycle Centre, a project concerning this topic is ongoing since 2018. 12 methods have been analysed and validated against criteria such as easy to use, comprehensibility, legitimisation and more. Still no definite result could be detected. All mentioned aspects are sketched in Figure 5. 


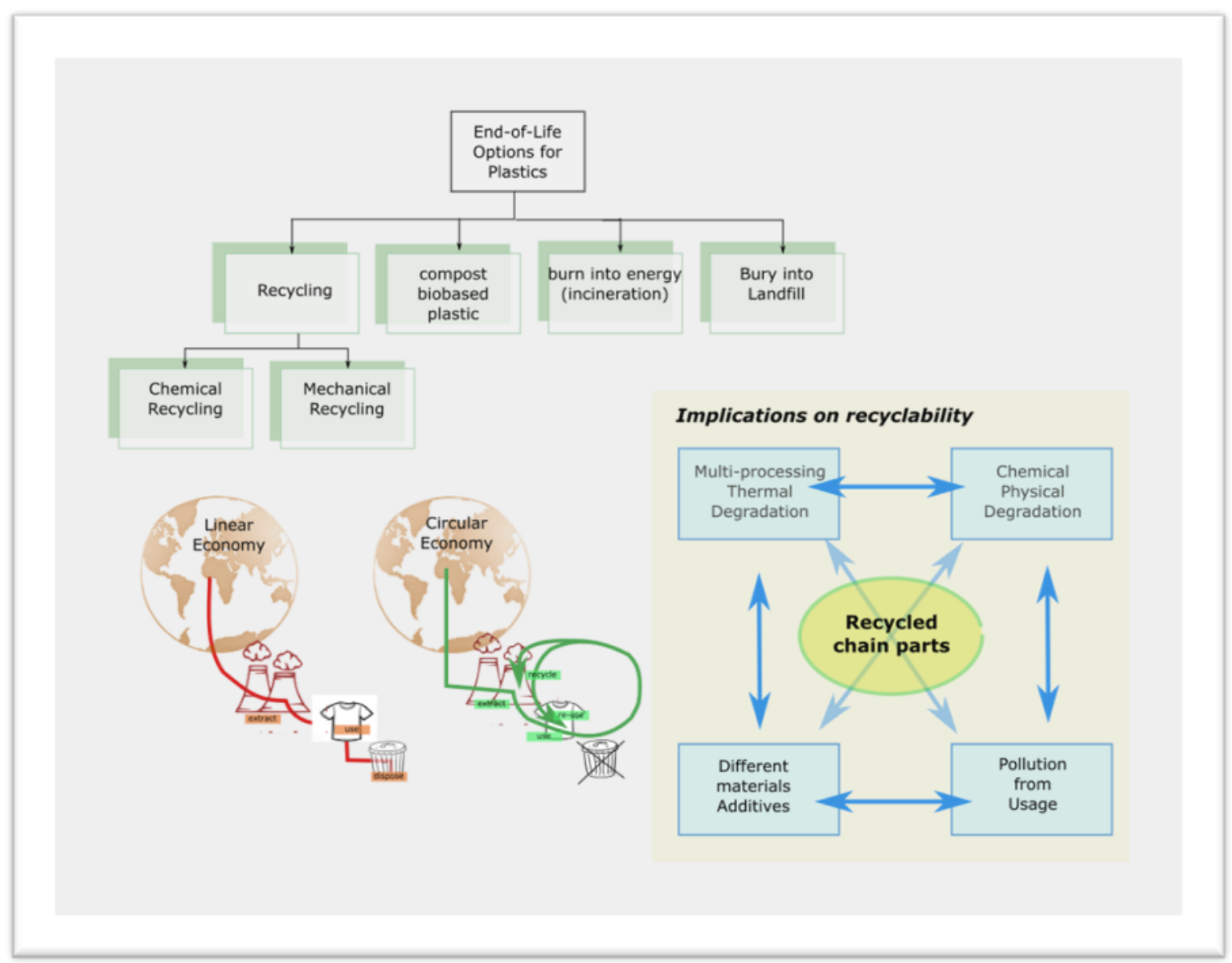

Figure 5: Aspects of End-of-Live for CCS

\section{Results}

There is no challenge to adopt the method of LCA to chain conveyor systems. As expected, the main influence occurs in the use-phase of an CCS. Therefore, design modifications for reducing the friction could be helpful to decrease the energy consumption. Real environmental impact reduction can be achieved, if the power of engine is adapted to the occurring consumption. An optimized efficiency level should be targeted. Also, exploitations of using recycled (chain-links of POM) or used (bolt of steel) chain components can decrease the environmental impact. Furthermore, these activities belong to the concept of circular economy, which gains to return used materials or product into the circle. This would reduce the resource depletion pressure in the world. Also, a prolongation of the use-phase can reduce the environmental burdens, this can be achieved through material optimization or modular construction.

For publishing LCA results of more environmentally friendly products EPDs could be helpful. They are a policy tool of integrated product policy, which obtain to push their market penetration. The buyer can use the information about environmental performance of products, within their life-cycle, to compare and to choose the best one. Reliable results in EPDs can only be published, if a product category rule exists. For CCS there a PCR has not yet been developed. The developing process is on progress, existing PCR and EPDs were 
analysed to find out, about the challenges. Unfortunately, EPDs are only comparable to a limited extend. Reasons for this are the incomplete fulfilment of the specifications in the PCR but also structural limits, caused for example by wrong chosen functional Units. For more details see [17].

\section{Discussion}

How can the purposes of EPDs, which are comparison and publishing of environmental information, be achieved? Which role does the instrument of PCR play, what are the conclusions to be drawn, of the still existing PCR and EPD development process to do better within the development of a PCR for "Continuous conveyor chain systems". Which role do the functional Unit, the boundary settings and other play? Does EPD provide readable, understandable results for layman to interpret? All these questions cannot be sufficiently answered, but are topic of the ongoing research [18].

Also, aspects like technical properties of recycled plastic materials, are on examination. The superordinate goal of all research is to find out all influences on environmental impacts. How can CCS become environmentally friendly and how this can target to achieve the climate goals, thus to avoid climate crises.

\section{Acknowledgement}

The authors would like to thanks the Röchling Stiftung ${ }^{\circledR}$ for financial support.

\section{References}

[1] IPCC, 2013: Summary for Policymakers. In: Climate Change 2013: The Physical Science Basis. Contribution of Working Group I to the Fifth Assessment Report of the Intergovernmental Panel on Climate Change [Stocker, T.F., D. Qin, G.-K. Plattner, M. Tignor, S.K. Allen, J. Boschung, A. Nauels, Y. Xia, V. Bex and P.M. Midgley (eds.)]. Cambridge University Press, Cambridge, United Kingdom and New York, NY, USA.

[2] Julian M. Allwood,Chapter 30 - Squaring the Circular Economy: The Role of Recycling within a Hierarchy of Material Management Strategies, [Ernst Worrell, Markus A. Reuter (eds.)]. Handbook of Recycling, Elsevier, 2014, pp. 445-477, ISBN 9780123964595

[3] www.skepticalscience.com, last access 04.09.2002

[4] European Comission: Report from the Commission to the European parliament and the council: Preparing the ground for raising long-term ambition EU Climate Progress Report 2019, 31.10.2019, Brüssel

[5] DIRECTIVE 2009/125/EC OF THE EUROPEAN PARLIAMENT AND OF THE COUNCIL of 21 October 2009, establishing a framework for the setting of ecodesign requirements for energy-related products.

[6] DIN- Normenausschuss Grundlagen des Umweltschutzes (NAGUS), DIN EN ISO 14044: Umweltmanagement - Ökobilanz - Anforderungen und Anleitungen (ISO 14044:2006 + Amd1:2007); Deutsche Fassung EN ISO 14044:2006 + A1:2018

[7] DIN Normenausschuss: Grundlagen des Umweltschutzes (NAGUS), DIN EN ISO 14040: Umweltmanagement - Ökobilanz - Grundlagen und Rahmenbedingungen (ISO 14040:2006) 
[8] Walter Klöpffer and Birgit Grahl: Life Cycle Assessment (LCA), a guide to best practice, 2014, Wiley-VCH Verlag GmbH \& Co. KGaA, Weinheim, Germany, ISBN 978-3-527-32986-1

[9] European Commission - Joint Research Centre - Institute for Environment and Sustainability: International Reference Life Cycle Data System (ILCD) Handbook - General guide for Life Cycle Assessment - Detailed guidance. First edition March 2010. EUR 24708 EN. Luxembourg. Publications Office of the European Union; 2010

[10] IPCC, 2013: Climate Change 2013: The Physical Science Basis. Contribution of Working Group I to the Fifth Assessment Report of the Intergovernmental Panel on Climate Change [Stocker, T.F., D. Qin, G.-K. Plattner, M. Tignor, S.K. Allen, J. Boschung, A. Nauels, Y. Xia, V. Bex and P.M. Midgley (eds.)]. Cambridge University Press, Cambridge, United Kingdom and New York, NY, USA, 1535 pp.

[11] Charter, Martin. (2001). Integrated Product Policy (IPP) and Eco-Product Development (EPD). Journal of Sustainable Product Design. 10. 672 - 677. http://dx.doi.org/10.1109/.2001.992445.

[12] Ecolabelindex.com, last access 15.09.2020

[13] Sara Toniolo, Anna Mazzi, Matteo Simonetto, Filippo Zuliani, Antonio Scipioni: Mapping diffusion of Environmental Product Declarations released by European program operators, Sustainable Production and Consumption, Volume 17, 2019, pp. 85-94, ISSN 2352-5509, https://doi.org/10.1016/j.spc.2018.09.004.

[14] Nikolay Minkov and Laura Schneider and Annekatrin Lehmann and Matthias Finkbeiner, Type \{III\} Environmental Declaration Programmes and harmonization of product category rules: status quo and practical challenges, Journal of Cleaner Production, Elsevier, 2015, volume 94, pp. 235-246, http://dx.doi.org/10.1016/j.jclepro.2015.02.012

[15] aclca.org, last access 15.09.2020

[16] Tasaki et. al: international Survey of the costs of assessment for environmental product declarations, 2017, CIRP Conference on Life Cycle Engineering, http://dx.doi.org/10.1016/j.procir.2016.11.158

[17] Europäische Kommission: COMMUNICATION FROM THE COMMISSION TO THE EUROPEAN PARLIAMENT, THE COUNCIL, THE EUROPEAN ECONOMIC AND SOCIAL COMMITTEE AND THE COMMITTEE OF THE REGIONS: A new Circular Economy Action Plan, For a cleaner and more competitive Europe, Brussels, 11.03.2020, https://eur-lex.europa.eu/legal-content/EN/TXT/HTML/?uri=CELEX:52020DC0098\&from=EN

[18] Lüdemann et. al., Produkt-Umwelterklärungen für Stetigförderer - Verbesserung der Lesbarkeit, Vortrag auf der Logistikwerkstatt-Graz, 2020 